\title{
Riboflavin deficiency in man: effects on haemoglobin and reduced glutathione in erythrocytes of different ages
}

\author{
BY HILARY J. POWERS* AND D. I. THURNHAM \\ Department of Human Nutrition, London School of Hygiene and Tropical Medicine, \\ London WCIE $7 \mathrm{HT}$
}

(Received 2̇8 February 1980-Accepted 21 April 1981)

\begin{abstract}
1. Erythrocytes (RBC) from control and marginally riboflavin-deficient subjects were fractionated into nine fractions using a discrete density gradient.

2. Glutathione reductase (NAD(P)H: glutathione oxidoreductase; $E C$ 1 .6.4.2) activity and aspartate aminotransferase (EC 2.6.1.1) activity (with and without the appropriate co-enzymes) reduced glutathione, methaemoglobin, sulphaemoglobin and oxyhaemoglobin and susceptibility to peroxide were measured in RBC in the different fractions.

3. Glutathione reductase and aspeirtate aminotransferase activities and concentrations of reduced glutathione and oxyhaemoglobin all declined with age, while methaemoglobin, sulphaemoglobin and susceptibility to peroxide increased with age.

4. The only significant differences $\mathrm{r}$ oted in the $\mathrm{RBC}$ from marginally-riboflavin-deficient subjects by comparison with controls, were lower glutathion: reductase activities and higher concentrations of methaemoglobin.

5. The role of riboflavin in those sytems controlling RBC integrity is discussed.
\end{abstract}

Severe riboflavin deficiency is not a major nutritional problem in the United Kingdom, but marginal or biochemical riboflavin deficiency was reported in $30 \%$ of people over 65 years of age living in their own homes (Thurnham \& Stephen, 1975; Department of Health and Social Security, 1979). Experimentally-induced riboflavin deficiency in man and animals is associated with a number of physiological and biochemical lesions, notably with an interference in iron metabolism and an impaired production of erythrocytes (RBC) from the bone marrow (Alfrey \& Lane, 1970; Hassan, 1978). A previous report indicated that erythrocyte glutathione reductase $(\mathrm{NAD}(\mathrm{P}) \mathrm{H}$ : glutathione oxidoreductase; $E C$ 1.6.4.2; EGR) a flavin-dependent enzyme, declined in activity with increasing RBC age and that riboflavin deficiency may be associated with a reduced survival time of $R B C$ in vivo (Powers \& Thurnham, 1976). This paper enlarges on these studies paying particular attention to the possible disturbance of RBC metabolism resulting from biochemical riboflavin deficiency.

\section{MATERIALS AND METHODS}

All reagents were obtained from BDH Ltd. unless otherwise stated.

\section{Subjects}

Elderly people (12) attending the Geriatric Day Centre at St Pancras Hospital, London NW1 OPE, and staff and students (16) of the Department of Human Nutrition, London School of Hygiene and Tropical Medicine, who were all apparently healthy, were screened for ariboflavinosis. A total of nine subjects were biochemically deficient in riboflavin (five elderly, four young) while the remainder were normal. Haematological and clinical information provided no evidence for additional nutrient deficiencies and none of the subjects were receiving oxidant drugs, which are known to influence RBC metabolism (Kellermeyer et al. 1962).

\footnotetext{
- Present address: Department of Food and Biological Sciences, The Polytechnic of North London, Holloway Road, London N7 8BR.
} 
Not all assays were performed on every sample since new measurements were introduced as the project developed and there was not always sufficient blood available.

\section{Riboflavin status}

EGR activity in $0.1 \mathrm{ml}$ of a haemolysate $(0.1-2.0 \mathrm{mg}$ haemoglobin) was measured in $0.1 \mathrm{M}$-phosphate buffer (pH 7.4), $2.3 \mathrm{~mm}^{-\mathrm{K}_{2}}$ EDTA and $0.889 \mathrm{~mm}$-oxidized glutathione in the presence and absence of $3 \mu \mathrm{M}-\mathrm{FAD}$ in a reaction initiated by $80 \mu \mathrm{M}-\mathrm{NAD}(\mathrm{P}) \mathrm{H}$ in a total volume of $3.6 \mathrm{ml}$. Cuvettes were incubated for $5 \mathrm{~min}$ at $37^{\circ}$ before the addition of NAD(P)H and the decrease in absorbance at $334 \mathrm{~nm}$ was recorded over $10 \mathrm{~min}$ at $37^{\circ}$.

Riboflavin status was assessed on the basis of an activity coefficient (AC) which was calculated from:

EGR activity with added FAD

$\overline{\text { EGR activity without added FAD }}$,

where values $\geqslant 1 \cdot 30$ indicated riboflavin deficiency.

\section{Aspartate aminotransferase (L-aspartate: 2-oxoglutarate aminotransferase; EC 2.6.1.1;AST)}

The method used was a modified version of that described by Wilkinson et al. (1972). The activity of AST in $0.1 \mathrm{ml}$ haemolysate was measured in a system consisting of $0.118 \mathrm{~mm}-$ NADH, 0.5 I.U. malate dehydrogenase (EC 1.1.1.37; Sigma), 0.127 M-L-aspartic acid and $0.1 \mathrm{M}$-potassium phosphate $(\mathrm{pH} 7.4)$ buffer with or without $0.126 \mathrm{~mm}$-pyridoxal phosphate in a total volume of $3.0 \mathrm{ml}$ in a reaction initiated by $\alpha$-oxoglutaric acid to give a final concentration of $6.7 \mathrm{mM}$. Cuvettes were incubated at $37^{\circ}$ for $5 \mathrm{~min}$ before the addition of the oxoglutaric acid. The fall in absorbance at $340 \mathrm{~nm}$ was recorded over $10 \mathrm{~min}$ at $37^{\circ}$.

\section{Density gradient separation of $R B C$}

Aqueous solutions of Ficoll (Pharmacia) were prepared containing (g/l) 160, 192, 220, 250, 268, 278, 296, 330 and 350 and were left over night at $4^{\circ}$ to dissolve. Triosil (Vestric, Cheshire) in distilled water $(340 \mathrm{~g} / \mathrm{l})$ was added to each solution of Ficoll in the proportion $2: 3(\mathrm{v} / \mathrm{v})$ providing solutions of the following calculated densities: $1 \cdot 100,1 \cdot 107,1 \cdot 113,1 \cdot 119$, $1 \cdot 123,1 \cdot 125,1 \cdot 129,1 \cdot 135$ and $1 \cdot 140 \mathrm{~g} / \mathrm{ml}$ (Turner et al. 1974). The final solutions contained a calculated $201 \mathrm{mEq} / 1$ which is higher than that of physiological saline $(154 \mathrm{~m} \mathrm{eq} / 1)$. However, microscopic examination of cells from all fractions showed no evidence of crenation. Furthermore, the object of the fractionation was to separate RBC into fractions of different ages and the use of the marker enzyme AST confirmed the chronological nature of the separation. Any shrinkage of RBC which occurred therefore should not alter the validity of the results. Portions $(1.8 \mathrm{ml})$ of progressively-less-dense solutions were layered into $17 \mathrm{ml}$ cellulose nitrate tubes (Beckmann) without mixing the different solutions. Portions of washed packed RBC $(1 \mathrm{ml})$ were layered on top of the gradients and finally liquid paraffin was added to within $2 \mathrm{~mm}$ from the top of each tube. Tubes were centrifuged in a Beckmann SW 27.1 swing-out rotor for $2 \mathrm{~h}$ at $4^{\circ}$ and $65000 \mathrm{~g}$ (average). After centrifuging, paraffin at the top of each tube and the fluffy white layer of leucocytes above the least-dense gradient solution were removed with a Pasteur pipette and discarded. Nine fractions of RBC were collected by disposable pipettes from positions progressively further down the gradient; the least dense being number 1, etc. Any RBC which remained firmly adhered to the base of the centrifuge tube after washing twice with isotonic saline $(9 \mathrm{~g}$ sodium chloride/l) were discarded. $\mathrm{RBC}$ were washed twice in buffered saline $\left(0.8 \mathrm{mM}-\mathrm{KH}_{2} \mathrm{PO}_{4}\right.$, $2.76 \mathrm{mM}^{-\mathrm{K}_{2}} \mathrm{HPO}_{4}, 0.14 \mathrm{mM}-\mathrm{NaCl}, \mathrm{pH} 7 \cdot 4$ ). 
Reduced glutathione (GSH)

The method of Beutler et cl. (1963) was used.

\section{Estimation of haemoglobin and derivatives}

Haemoglobin $(\mathrm{Hb})$ was measured by the cyanmethaemoglobin method (Crosby \& Houchin, 1957). $\mathrm{Hb}$ derivatives were estimated using the method of Evelyn \& Malloy (1938). To minimize changes in methaemoglobin concentration, after the fractionation washed RBC were immediately added to a $16.7 \mathrm{~mm}$-potassium phosphate buffer (pH 6.6), covered with a thin layer of paraffin oil and stored overnight at $-20^{\circ}$ before assay (about $20 \mathrm{~h}$ ).

\section{Peroxidative haemolysis}

RBC $(2.5 \mathrm{ml}$ of suspensions at a packed cell volume of 0.05 in a buffered saline solution containing $2 \mathrm{mM}$-sodium azide) were added to $2.5 \mathrm{ml}$ buffered saline containing $10 \mathrm{mM}$ hydrogen peroxide. Sample: blanks containing no $\mathrm{H}_{2} \mathrm{O}_{2}$ and reagent blanks containing no RBC were also prepared. Total haemolysates were likewise prepared by adding equal volumes of each suspension to distilled water. Suspensions were incubated for $1 \mathrm{~h}$ with continuous shaking at $37^{\circ}$ then centrifuged at $5000 \mathrm{~g}$ for $15 \mathrm{~min}$. The percentage of cells which haemolysed were calculated as:

$$
\frac{\mathrm{Hb}_{8}}{\mathrm{Hb}_{t}} \times 100,
$$

where $\mathrm{Hb}_{\mathrm{g}}$ is the haemoglobin concentration $(\mathrm{mg} / \mathrm{ml})$ in the sample supernatant fraction and $\mathrm{Hb}_{t}$ is the haemoglobin concentration in a total haemolysate of the sample.

\section{RESULTS}

Enzyme activity in $R B C$ of different ages

RBC increase in density as they age (Borun et al. 1957). Density gradient ultracentrifugation was therefore employed to separate cells into fractions of different mean densities. It is well established that the activity of AST declines with increasing age of RBC (Chapman \& Schaumberg, 1967; Fischer \& Walter, 1971). The fall in specific activity of AST in RBC fractions of increasing density (Table 1) therefore confirmed that fractions 1-9 contained RBC of increasing mean age.

The specific activity of EGR declined in a similar fashion to AST (Table 1). It was also noted that both basic and stimulated activities in the riboflavin-deficient subjects were almost always lower than those in the corresponding fractions of normal subjects. A statistical analysis (nested variance) on results from all subjects indicated, furthermore, that EGR activity was significan:ly higher in the oldest cells (fraction 9 compared with fraction 6), but that there was no such rise in AST activity. The physiological implications of this observation are discussed elsewhere (Powers et al. 1981).

\section{Erythrocyte GSH concentration}

Correlations between RBC density (RBC age) and GSH concentrations were negative and highly significant in both normal $(P<0.001)$ and riboflavin-deficient $(P<0.001)$ subjects (Fig. 1). Somewhat lower mean concentrations of GSH were measured in older RBC from subjects with riboflavin deficiency when compared with normal subjects, but the differences were not statistically significant (analysis of covariance). 


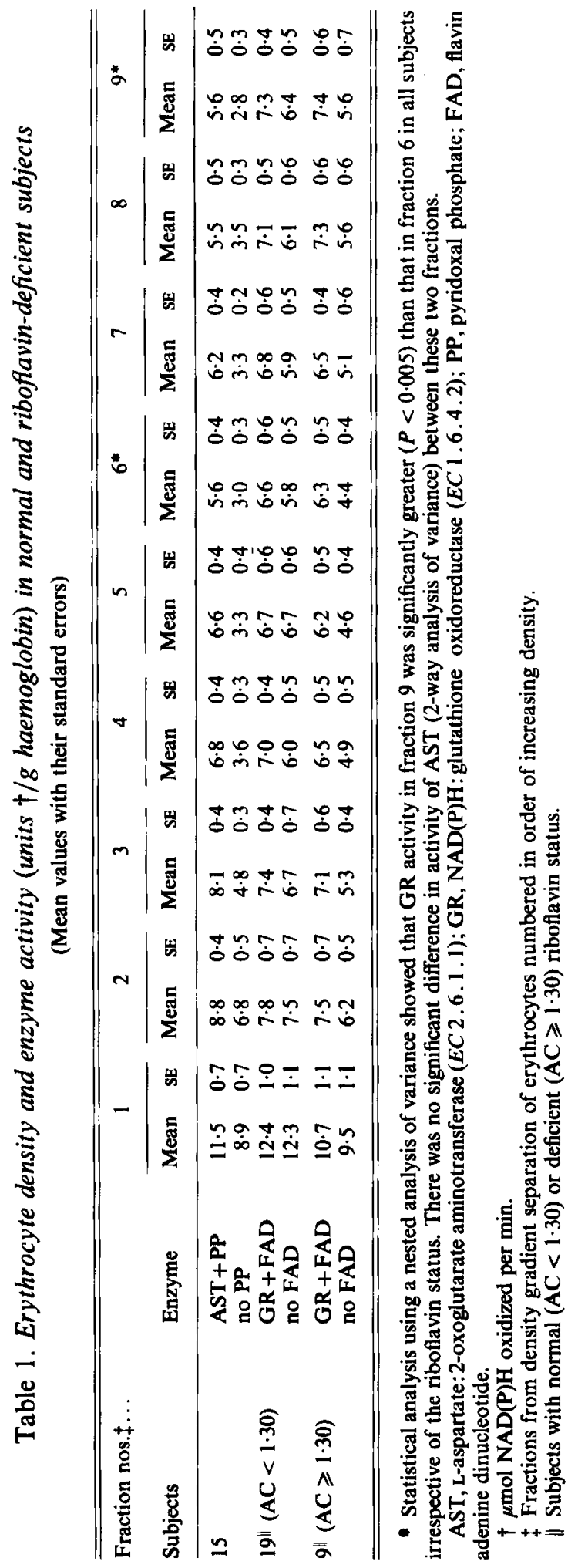




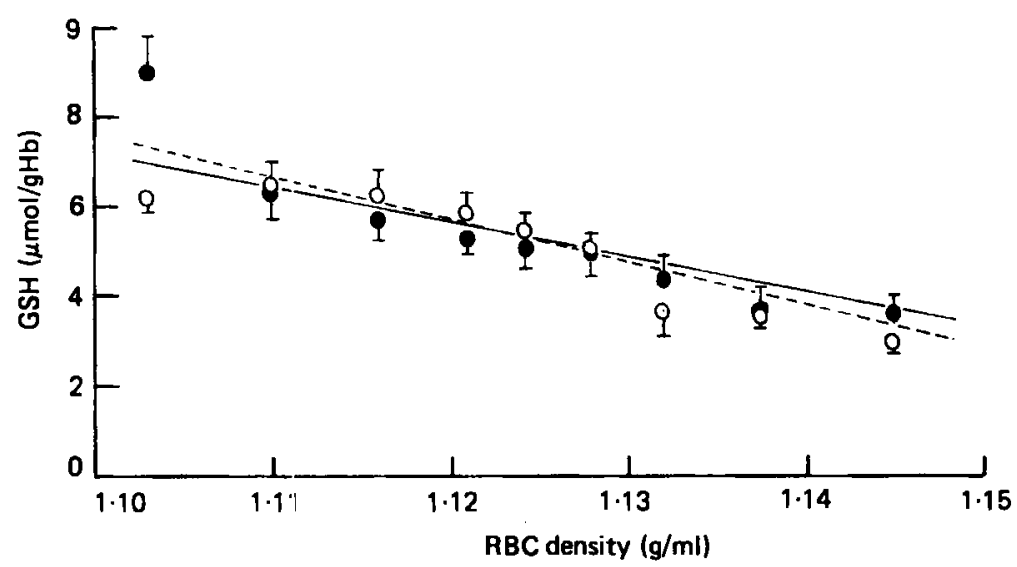

Fig. 1. Erythrocytes (RBC) from nine control (O-O) and riboflavin-deficient subjects $(\mathrm{O}---\mathrm{O})$ were fractionated by density gradient separation as described on p. 258. Reduced glutathione (GSH) was measured in duplicate on all RBC fractions from each subject. Regression lines shown were calculated from all values obtained. Point: shown are means ( $\pm \mathrm{SE}$ ) of GSH concentrations of RBC in each fraction. Regression equation for control subjects: GSH $\mu \mathrm{mol} / \mathrm{g}$ haemoglobin $(\mathrm{Hb})=\mathrm{RBC}$ density $(\mathrm{g} / \mathrm{ml})$ $(-89.03)+105.27(r \quad 0.58, P<: 0.001)$, for deficient subjects $\mathrm{GSH} \mu \mathrm{mol} / \mathrm{g} \mathrm{Hb}=\mathrm{RBC}$ density $(\mathrm{g} / \mathrm{ml})$ $(-109 \cdot 19)+127.90(r 0.81, P<0.001)$.

\section{$\mathrm{Hb}$ derivatives}

Analyses of covariance were also done on data for the haemoglobin derivatives measured in RBC from normal and riboflavin-deficient subjects (Fig. 2). Significant differences between the rates of decline in proportion of oxyhaemoglobin $(0 x y H b, P<0.05)$ or increase in proportion of methaemoglobin (MHb, $P<0.05$ ) with $\mathrm{RBC}$ age were obtained but the rate of increase of sulphaemoglobin $(\mathrm{SHb})$ with $\mathrm{RBC}$ age in normal and riboflavin-deficient subjects was not significantly different. The analyses also confirmed that there was less OxyHb $(P<0.05)$, more MHb $(P<0.01)$ and more SHb $(P<0.05)$ in RBC of all ages from riboflavin-deficient by comparison with normal subjects.

Regression analyses were also performed on GSH and MHb values for each of the subjects for which data is shown in Fig. 2, that is, four normal and three subjects with marginal riboflavin deficiency (Table 2). GSH concentrations and MHb showed significant negative correlations in three of the normal, and two of the riboflavin-deficient subjects (Table 2).

\section{Peroxidative haemolysis}

Older cells incubated with $\mathrm{H}_{2} \mathrm{O}_{2}$ showed a consistently greater extent of haemolysis than young cells from the same subjects (Table 3). Nested analysis of variance showed that while there were differences in the extent of haemolysis between the different fractions $(P<0.005)$, there was no difference betwreen RBC of normal and deficient subjects. Further analysis of results from subjects with normal riboflavin status, by the paired $t$ test, showed that the extent of haemolysis in fraction nos. 2,3 and 4 was significantly greater than that in fraction no. 1 ( $P<0.05, P<0.02$ and $P<0.001$ respectively). Likewise, results from riboflavindeficient subjects showed that haemolysis in fraction nos. 2, 3 and 4 was greater than that in fraction no. $1(P<0.05, P<0.02$ and $P<0.001$ respectively). 


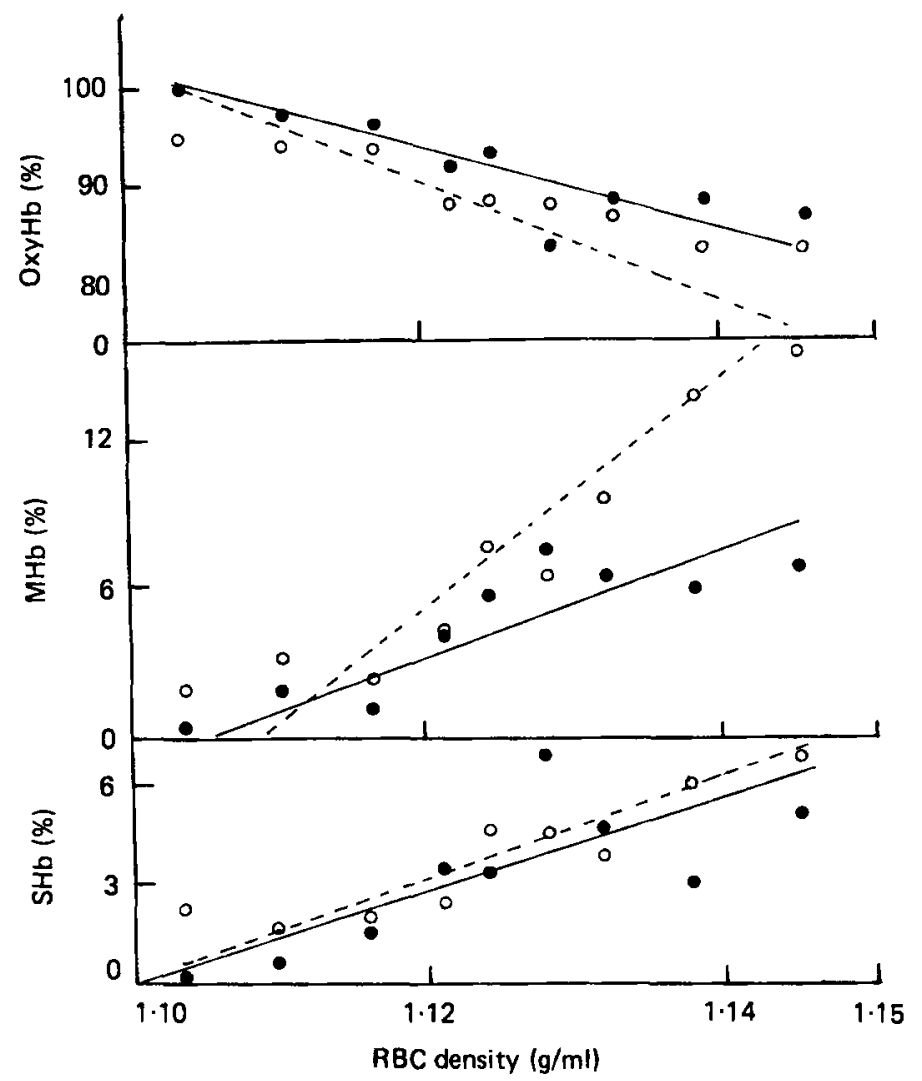

Fig. 2. Erythrocytes from four control (O-O) and three riboflavin-deficient subjects $\left(\mathrm{O}--\mathrm{O}^{-}\right.$) were fractionated by density gradient centrifugation as described on p. 258. Methaemoglobin (MHb), sulphaemoglobin (SHb) and oxyhaemoglobin (OxyHb) were measured in duplicate and expressed as a percentage of total haemoglobin (Hb). Regression lines shown were obtained from all values (equations below). Points shown are means ( $\pm \mathrm{SE}$ ) of measurements done on $\mathrm{RBC}$ in each fraction. Control subjects:

$$
\begin{aligned}
\text { OxyHb }(\%)= & \text { RBC density }(\mathrm{g} / \mathrm{ml})(-399.84)+542.25 \\
& (r-0.69, P<0.001), \\
\text { MHb }(\%)= & \text { RBC density }(\mathrm{g} / \mathrm{ml})(233.38)+(-258.36) \\
\text { SHb }(\%)= & \text { RBC density }(\mathrm{g} / \mathrm{ml})(148.06)+(-163.04) \\
& (r 0.46, P<0.01),
\end{aligned}
$$

Riboflavin-deficient subjects:

$$
\begin{aligned}
& \text { OxyHb }(\%)= \operatorname{RBC} \text { density }(\mathrm{g} / \mathrm{ml})(-603.03)+767.05 \\
& \text { MHb }(\%)= \operatorname{RBC} \text { density }(\mathrm{g} / \mathrm{ml})(473.27)+(-524.97) \\
&(r-0.76, P<0.001) \\
& \text { SHb }(\%)= \text { RBC density }(\mathrm{g} / \mathrm{ml})(157.38)+(-173.01) \\
&(r 0.54, P<0.01) .
\end{aligned}
$$

\section{DISCUSSION}

The results have been analysed only in terms of the presence and absence of riboflavin deficiency. Sex was not shown to influence the measure of riboflavin status or that of the other indices measured in this study. Old age has been associated with a slightly higher proportion of denser (older) RBC in the blood (Powers \& Thurnham, 1976; 1980a). While a higher proportion of old RBC might influence concentrations of substances in whole blood 
Table 2. Reduced glutathione (GSH) methaemoglobin $(M H b)$ in erythrocytes $(R B C)$ of different densities from control $(A C<1 \cdot 30)$ and riboflavin-deficient $(A C \geqslant 1 \cdot 30)$ subjects

\begin{tabular}{|c|c|c|c|c|c|c|c|c|c|c|c|}
\hline $\begin{array}{l}\text { Fraction nos.*... } \\
\text { AC } \\
\text { of } \\
\text { RBC } \\
\text { GR }\end{array}$ & 1 & 2 & 3 & 4 & 5 & 6 & 7 & 8 & 9 & $r$ & $\begin{array}{c}\text { Statistical } \\
\text { significance } \\
\text { of } \\
\text { correlation } \\
P\end{array}$ \\
\hline $\begin{array}{lr}1.21 & \text { GSH } \\
\% & \text { MHb }\end{array}$ & $\begin{array}{c}10 \cdot 6 \\
0\end{array}$ & $\begin{array}{l}8 \cdot 5 \\
2 \cdot 2\end{array}$ & $\begin{array}{l}7.7 \\
0.6\end{array}$ & $\begin{array}{l}7.0 \\
8.8\end{array}$ & $\begin{array}{l}6.7 \\
5.0\end{array}$ & $\begin{array}{r}6 \cdot 6 \\
10 \cdot 1\end{array}$ & $\begin{array}{r}5 \cdot 5 \\
12 \cdot 0\end{array}$ & $\begin{array}{l}4 \cdot 6 \\
8 \cdot 2\end{array}$ & $\begin{array}{l}3.8 \\
8 \cdot 5\end{array}$ & $\begin{array}{c}-0.72 \\
-\end{array}$ & $<0.05$ \\
\hline $1 \cdot 10 \underset{\%}{\mathrm{GSH}}$ & $\begin{array}{l}7 \cdot 2 \\
0\end{array}$ & $\begin{array}{l}6 \cdot 4 \\
1 \cdot 4\end{array}$ & $\begin{array}{l}5.7 \\
1.6\end{array}$ & $\begin{array}{l}5 \cdot 0 \\
2 \cdot 2\end{array}$ & $\begin{array}{l}4.2 \\
2 \cdot 8\end{array}$ & $\begin{array}{l}4.5 \\
2.0\end{array}$ & $\begin{array}{l}4 \cdot 0 \\
5 \cdot 6\end{array}$ & $\begin{array}{l}3 \cdot 6 \\
3 \cdot 2\end{array}$ & $\begin{array}{l}3.4 \\
7.9\end{array}$ & $\begin{array}{c}-0.80 \\
-\end{array}$ & $\begin{array}{c}<0.02 \\
-\end{array}$ \\
\hline $1 \cdot 10 \begin{array}{r}\text { GSH } \\
\% \text { MHb }\end{array}$ & $\begin{array}{l}7.8 \\
0\end{array}$ & $\begin{array}{l}7 \cdot 1 \\
0\end{array}$ & $\begin{array}{l}6.7 \\
1.8\end{array}$ & $\begin{array}{l}6 \cdot 4 \\
3 \cdot 4\end{array}$ & $\begin{array}{l}5.8 \\
3.8\end{array}$ & $\begin{array}{l}5 \cdot 6 \\
4 \cdot 2\end{array}$ & $\begin{array}{l}4 \cdot 3 \\
4.0\end{array}$ & $\begin{array}{l}3.7 \\
7.6\end{array}$ & $\begin{array}{l}3 \cdot 5 \\
6 \cdot 3\end{array}$ & $\begin{array}{c}-0.93 \\
-\end{array}$ & $<0.001$ \\
\hline $1.28 \underset{\%}{\operatorname{GSH}}$ & $\begin{array}{l}6 \cdot 6 \\
0\end{array}$ & $\begin{array}{l}6.0 \\
1.9\end{array}$ & $\begin{array}{l}5 \cdot 6 \\
0\end{array}$ & $\begin{array}{l}5 \cdot 3 \\
0.6\end{array}$ & $\begin{array}{l}4 \cdot 8 \\
2 \cdot 8\end{array}$ & $\begin{array}{r}4 \cdot 2 \\
14 \cdot 0\end{array}$ & $\begin{array}{l}3 \cdot 8 \\
3 \cdot 4\end{array}$ & $\begin{array}{l}3 \cdot 2 \\
2 \cdot 9\end{array}$ & $\begin{array}{l}3 \cdot 4 \\
4 \cdot 2\end{array}$ & $\begin{array}{c}-0 \cdot 46 \\
-\end{array}$ & NS \\
\hline $1.44 \underset{\%}{\text { MHb }}$ & $\begin{array}{l}8 \cdot 6 \\
0\end{array}$ & $\begin{array}{l}8 \cdot 6 \\
2 \cdot 5\end{array}$ & $\begin{array}{l}8 \cdot 0 \\
0 \cdot 4\end{array}$ & $\begin{array}{l}7 \cdot 6 \\
0.3\end{array}$ & $\begin{array}{l}6.4 \\
1.5\end{array}$ & $\begin{array}{l}6 \cdot 2 \\
4 \cdot 5\end{array}$ & $\begin{array}{l}5 \cdot 3 \\
5 \cdot 5\end{array}$ & $\begin{array}{r}4 \cdot 7 \\
13 \cdot 6\end{array}$ & $\begin{array}{l}3 \cdot 4 \\
9 \cdot 1\end{array}$ & $\begin{array}{c}-0.83 \\
-\end{array}$ & $<0.01$ \\
\hline $1.38 \underset{\%}{\text { GSH }}$ & $\begin{array}{l}6 \cdot 4 \\
3 \cdot 3\end{array}$ & $\begin{array}{l}5 \cdot 8 \\
5 \cdot 0\end{array}$ & $\begin{array}{l}5 \cdot 6 \\
2 \cdot 8\end{array}$ & $\begin{array}{l}5 \cdot 7 \\
7 \cdot 6\end{array}$ & $\begin{array}{r}5 \cdot 4 \\
10 \cdot 4\end{array}$ & $\begin{array}{r}4 \cdot 0 \\
14 \cdot 0\end{array}$ & $\begin{array}{r}3 \cdot 1 \\
20 \cdot 7\end{array}$ & $\begin{array}{r}3 \cdot 1 \\
22 \cdot 9\end{array}$ & $\begin{array}{r}3.0 \\
23.9\end{array}$ & $\begin{array}{c}-0.97 \\
-\end{array}$ & $<0.001$ \\
\hline $1.55 \begin{array}{r}\text { GSH } \\
\% \text { MHb }\end{array}$ & $\begin{array}{l}7 \cdot 3 \\
1 \cdot 2\end{array}$ & $\begin{array}{l}5 \cdot 7 \\
2 \cdot 4\end{array}$ & $\begin{array}{l}5 \cdot 7 \\
4 \cdot 0\end{array}$ & $\begin{array}{l}5 \cdot 3 \\
4 \cdot 3\end{array}$ & $\begin{array}{l}4 \cdot 5 \\
4 \cdot 7\end{array}$ & $\begin{array}{l}4.2 \\
1.7\end{array}$ & $\begin{array}{l}2 \cdot 2 \\
2 \cdot 9\end{array}$ & $\begin{array}{l}2.9 \\
4.5\end{array}$ & $\begin{array}{r}2.3 \\
16.0\end{array}$ & $\begin{array}{c}-0.54 \\
-\end{array}$ & NS \\
\hline
\end{tabular}

AC, activation coefficient (measure of riboflavin status, see p. 258); GR, glutathione reductase (NAD(P)H: gluta thione oxidoreductase, $E C$ 1.6.4.2); NS, not significant; GSH, reduced glutathione; MHb, methaemoglobin.

- Fractions from density gradient separation of RBC numbered in order of increasing density.

Table 3. Cell age and susceptibility to haemolysis (\% haemolysis) in hydrogen peroxide in control $(N \dagger)$ and riboflavin-deficient $\left(D_{\ddagger}^{\dagger}\right)$ subjects

\begin{tabular}{|c|c|c|c|c|c|c|c|c|}
\hline \multirow{2}{*}{$\frac{\text { Fraction no. }}{\text { Density rangell }}$} & \multicolumn{2}{|c|}{1} & \multicolumn{2}{|c|}{2} & \multicolumn{2}{|c|}{3} & \multicolumn{2}{|c|}{4} \\
\hline & \multicolumn{2}{|c|}{$1 \cdot 103-1 \cdot 113$} & \multicolumn{2}{|c|}{$1 \cdot 114-1 \cdot 118$} & \multicolumn{2}{|c|}{$1 \cdot 119-1 \cdot 130$} & \multicolumn{2}{|c|}{$>1 \cdot 130$} \\
\hline Subject no. & $\mathbf{N}$ & $\mathbf{D}$ & $\mathbf{N}$ & D & $\mathbf{N}$ & D & $\mathbf{N}$ & D \\
\hline 1 & $18 \cdot 0$ & $6 \cdot 0$ & 20.5 & $13 \cdot 3$ & $19 \cdot 3$ & $11 \cdot 1$ & $22 \cdot 8$ & $18 \cdot 5$ \\
\hline 2 & $3 \cdot 0$ & 7.0 & $9 \cdot 1$ & $12 \cdot 0$ & $8 \cdot 2$ & $13 \cdot 5$ & $9 \cdot 3$ & $13 \cdot 4$ \\
\hline 3 & $13 \cdot 7$ & 6.0 & 14.0 & 2.9 & $14 \cdot 3$ & $5 \cdot 5$ & $20 \cdot 2$ & $13 \cdot 4$ \\
\hline 4 & $4 \cdot 5$ & $12 \cdot 0$ & $5 \cdot 1$ & $14 \cdot 2$ & 8.5 & 17.0 & 9.0 & $19 \cdot 1$ \\
\hline 5 & $4 \cdot 1$ & $4 \cdot 0$ & $5 \cdot 7$ & $7 \cdot 5$ & 6.9 & $11 \cdot 1$ & 9.9 & $12 \cdot 5$ \\
\hline 6 & $5 \cdot 0$ & - & 8.0 & - & $13 \cdot 0$ & - & $13 \cdot 0$ & - \\
\hline 7 & 3.0 & - & $4 \cdot 5$ & - & 6.3 & - & 8.8 & - \\
\hline Mean* & $7 \cdot 32$ & $7 \cdot 00$ & $9 \cdot 55$ & 9.98 & 10.92 & $11 \cdot 64$ & $13 \cdot 35$ & $15 \cdot 38$ \\
\hline SEM & $2 \cdot 26$ & $1 \cdot 34$ & $2 \cdot 19$ & $2 \cdot 11$ & $1 \cdot 80$ & 1.87 & $2 \cdot 18$ & $1 \cdot 40$ \\
\hline
\end{tabular}

- Statistical analysis: a nested analysis of all data showed that there was a significant difference $(P<0.005)$ between the fractions in the amoun1. of haemolysis which occurred. However, the amount of haemolysis in fractions of RBC from riboflavin deficient subjects was not significantly different from that found in the controls.

+ Mean AC (activation coefficient, measure of riboflavin status) of seven control subjects was $1 \cdot 18 \pm 0.03$ (SEM).

$\ddagger$ Mean AC of five riboflavin deficient subjects was $1.41 \pm 0.04$ (SEM).

\| Erythrocytes were separated by density gradient separation (see p. 258) and recombined in density ranges shown. 
and thus bias a comparison between normal and riboflavin-deficient subjects, all comparisons between normal and riboflavin-deficient $\mathrm{RBC}$ have been made on fractions of $\mathrm{RBC}$ of the same density.

It was previously reported that the proportion of older RBC in a sample was reduced in riboflavin-deficient subjects (Powers \& Thurnham, 1976). GR functions in the RBC to maintain glutathione in its reduced form, GSH, and requires riboflavin as FAD for this purpose. The maintenance of GSH may be important to RBC integrity for several reasons. Sulphydryl groups in RBC may be essential for maintaining structurally-important sulphydryl groups in R BC membranes (Jacob \& Jandl, 1962). Sulphydryl groups participate in oxidation-reduction reactions within RBC, notably those involving glutathione peroxidase ( $E C 1.11 .1 .7$; GSHPx), which functions to reduce potentially-harmful lipid peroxides in the cell (Cohen \& Hochstein, 1963). GSH functions as a coenzyme for some RBC enzymes notably glyceraldehyde-3-phosphate dehydrogenase $(E C$ 1.2.1.12) (Krimsky \& Racker, 1952). An accumulation of oxidized glutathione (GSSG) can inhibit hexokinase (EC 2.7.1.1) activity (Eldjarn \& Bremer, 1962) and might therefore threaten the energy supply of the RBC.

Marginal riboflavin status reduces the GR activity in RBC of all ages (Table 1) but appears to have little effect on the concentrations of GSH (Fig. 1). However, the RBC concentration of GSH is not necessarily a useful measure of the cell's ability to maintain GSH concentrations under stress in vivo. That is, the combined effect of age and riboflavin deficiency may make older RBC increasingly unable to supply GSH rapidly enough to meet metabolic requirements in the face of physiological oxidant stresses. Therefore older RBC may be removed from the circulation more rapidly than those from subjects with normal riboflavin status.

Incubating RBC with peroxide (Table 3) was an attempt to measure their potential ability to cope with oxidant stress, to which it is known that RBC are exposed during their passage through the circulation in vivo. Older cells from both biochemically riboflavin-deficient subjects showed significantly more haemolysis when exposed to peroxide than young cells from the same sample of blood (Table 3). However, there was no significant difference between the response of normal and riboflavin-deficient RBC to peroxide exposure. Haemolysis on exposure to peroxide may reflect the inability of RBC to maintain a supply of GSH for the peroxide-reducing enzyme GSHPx, and suggests that as RBC age, there is an increased susceptibility of the lipid components of the RBC membrane to damage caused by peroxidation. In the incubation medium used in the present study the activity of catalase (EC 1.11.1.6), an $\mathrm{RBC}$ enzyme capable of reducing high concentrations of $\mathrm{H}_{2} \mathrm{O}_{2}$ (Cohen \& Hochstein, 1963) was inhibited by sodium azide, thereby increasing the cell's reliance on GSHPx activity to detoxify peroxide. It may be that RBC from biochemically riboflavindeficient subjects are only marginally less capable of generating GSH than RBC from normal subjects in spite of reduced GR activity. Alternatively, the tendency for increased percentage haemolysis in the older fractions may be due to changes in membrane or other characteristics not directly associated with the generation of GSH.

The $\mathrm{H}_{2} \mathrm{O}_{2}$ incubation system is believed to be a method of testing the response of $\mathrm{RBC}$ to oxidation stress in that the extent of haemolysis correlates well with vitamin $\mathrm{E}$ status (Gross, 1976). The work of Levander and co-workers (Levander et al. $1977 a, b$; Levander et al. 1978), however, points out that no single in vitro system can monitor susceptibility of RBC to natural stress mechanisms. The marked anaemia in vitamin E-deficient, lead-poisoned rats, is characterized by RBC with increased mechanical fragility (Levander et al. 1975) but the filtration times through polycarbonate filters which is considered to indicate deformability (Levander et al. 1977 a) and resistance to peroxidation stresses (Levander $e t$ al. 1977b) are both increased. It was suggested that the anaemia of $\mathrm{Pb}$ 
poisoning accompanying vitamin $\mathrm{E}$ deficiency may have been due to a toughening effect of $\mathrm{Pb}$ on $\mathrm{RBC}$ membranes which made the $\mathrm{RBC}$ less flexible and more vulnerable to sequestration in the spleen.

It has also been suggested that malonaldehyde, a breakdown product of lipid peroxides, may have a similar effect to lead in that it appears to form Schiff bases by cross-linking with components of RBC membranes (Levander et al. 1978). In the bound form malonaldehyde is not measurable by the standard thiobarbituric acid assay (Desai \& Tappel, 1963; Goldstein \& McDonigh, 1975) and in fact we have shown that the formation of malonaldehyde on exposure of RBC to peroxide is apparently inversely proportional to cell age (Powers \& Thurnham, 1980 b). The work of Levander and co-workers (Levander $e t$ al. $1977 a, b$; Levander $e t$ al. 1978) points out therefore that response of RBC on exposure to peroxide in vitro is not alvays a good indication of RBC susceptibility to in vivo stresses.

MHb concentration in old RBC has previously been shown to exceed that in young RBC (Brewer et al. 1962). Results in this study confirmed that there is a progressive increase in $\mathrm{MHb}$ and $\mathrm{SHb}$ and a concomitant reduction in OxyHb with increasing age of RBC (Fig. 2). This suggests that during the lifetime of the $\mathrm{RBC}$, the cell becomes progressively less able to protect its $\mathrm{Hb}$ from changes which may ultimately lead to its denaturation and destruction. The formation of $\mathrm{MHb}$ is enhanced by oxidants and it has been suggested that GSH prevents the oxidation of $\mathrm{Hb}$ by acting as an alternative substrate for oxidant species via GSHPx activity (Hill et al. 1964). The significant inverse correlation between GSH concentrations and percentage $\mathrm{MHb}$ in red cells of different ages in most subjects (Table 2) supports this suggestion.

The cellular concentration of GSH, however, is not necessarily a good indication of the ability of the RBC to generate GSH as mentioned previously. Beutler \& Srivastava (1970) have suggested that GR activity of $\mathrm{RBC}$ must fall by more than $50 \%$ before the enzyme becomes rate-limiting. Activity of some RBC enzymes falls with increasing age of RBC(Voss et al. 1964) but in subjects with normal riboflavin status a fall in excess of $50 \%$ of the activity of the young RBC is uncommon even in the oldest cells (Table 1; Powers \& Thurnham, 1976). However, in riboflavin deficiency, GR activity of RBC might possibily be rate-limiting in several of the older fracticns since this activity is certainly well below $50 \%$ of that found in young RBC from subjects with good riboflavin status (Powers \& Thurnhan, 1976). In this connexion it is interesting to note that the three marginally-riboflavin-deficient subjects showed increased quantities of MHb in older cells (Table 2) although in the last subject listed, elevated MHb concentration was only marked in fraction no. 9.

It is possible that an increased concentration of erythrocyte $\mathrm{MHb}$ may be directly due to the flavin deficiency, since $\mathrm{MHb}$ reductases are believed to be flavin-dependent (Scott \& McGraw, 1962; Mutsuki ət al. 1978) but further work needs to be done to establish the importance of marginal riboflavin deficiency on the activity of $\mathrm{MHb}$ reductases. Nevertheless these results do reinforce the possibility that the GSH-GSHPx system may not be adequate to maintain $\mathrm{Hb}$ in a functional state in older cells in marginally-riboflavin-deficient subjects.

The absence of any significant differences other than the higher concentrations of $\mathrm{MHb}$ in the RBC of riboflavin-deficient subjects studied in this work may of course indicate that the GSH concentrations and sensitivity to peroxide in vitro are not affected by riboflavin deficiency. However, all these indices were adversely altered in RBC from rats with experimental riboflavin deficiency (Hassan \& Thurnham, 1977) so it may be that the very marginal state of deficiency in the human subjects was such that the systems which protect against oxidation were not seriously jeopardized. On the other hand, a fall in cellular GSH or an increased sensitivity to peroxide may so affect the viability of the cells that they are immediately removed from the circulation by the endogenous trapping mechanism. Alternatively, cells showing one or more of these metabolic alterations may have been 
amongst those lost by haemolysis during preparation of the cells for centrifugation or during the centrifugation period, or because of some undetermined characteristics which made them adhere to the wall of the fractionation tube. Answers to some of these questions may be obtained when RBC are studied from subjects with more severe riboflavin deficiency.

Finally it should be said that although MHb per se has not been shown to have a significant deleterious effect on the RBC (Jaffe, 1959) nevertheless, it is possible that the accompanying lowered GR activity in subjects with marginal riboflavin deficiency may be indicative of a general impairment of antioxidant systems and may be causally associated with a shortened RBC life span.

The authors thank the Medical Research Council and Department of Health and Social Security for financial support and the Central Research Fund, University of London, for assistance in purchasing a Beckmann SW27.1 swinging bucket rotor. The authors are also very grateful to Professor A. N. Exton-Smith, and other members of staff and patients at the Geriatric Day Centre, St. Pancras Hospital, for blood samples.

\section{REFERENCES}

Alfrey, C. P. \& Lane, M. (1970). Semin. Haematol. 7, 49.

Beutler, E., Duron, O. \& Kelly, B. (1963). J. lab. clin. Med. 61, 882.

Beutler, E. \& Srivastava, S. K. (1970). Nature, Lond. 226, 759.

Borun, E. R., Figueroa, W. G. \& Perry, S. M. (1957). J. clin. Invest. 36, 676.

Brewer, G. J., Tarlov, A. R., Kellermeyer, R. C. \& Alving, A. S. (1962). J. lab. clin. Med. 59, 905.

Chapman, R. G. \& Schaumberg, L. (1967). Brit. J. Haemat. 13, 665.

Cohen, G. \& Hochstein, P. (1963). Biochemistry, New York 2, 1420.

Crosby, W. D. \& Houchin, D. N. (1957). Blood 12, 1132.

Department of Health and Social Security (1979). Rep. Hlth Soc. Subj. no. 16.

Desai, I. D. \& Tappel, A. L. (1963). J. lipid Res. 4, 204.

Eldjarn, L. \& Bremer, J. (1962). Biochem. J. 84, 286.

Evelyn, K. A. \& Malloy, H. T. (1938). J. biol. Chem. 126, 655.

Fischer, I. \& Walter, H. (1971). J. lab. clin. Med. 78, 739.

Goldstein, B. D. \& McDonagh, E. M. (1975). Clin. Res. 23, 247A.

Gross, S. (1976). Semin. Heamatol. 13, 187.

Hassan, F. M. (1978). Erythrocyte pathophysiology of riboflavin deficiency in rats. PhD Thesis, University of London.

Hassan, F. M. \& Thurnham, D. I. (1977). Int. Z. Vitaminforsch. 47, 349.

Hill, A. S. Jr, Hart, A., Cartwright, G. E. \& Wintrobe, M. M. (1964). J. clin. Invest. 43, 17.

Jacob, H. S. \& Jandl, J. H. (1962). J. clin. Invest. 41, 779.

Jaffe, E. R. (1959). J. clin. Invest. 38, 1555.

Kellermeyer, R. W., Tarlov, A. R., Brewer, G. J., Carson, P. E. \& Alving, A. S. (1962). J. Am. med. Assoc. 180, 388.

Krimsky, I. \& Racker, E. (1952). J. biol. Chem. 198, 721.

Levander, O. A., Morris, V. C. \& Ferretti, R. J. (1977a) J. Nutr. 107, 363.

Levander, O. A., Morris, V. C. \& Ferretti, R. J. (1977b). J. Nutr. 107, 373.

Levander, O. A., Morris, V. C. \& Ferretti, R. J. (1978). J. Nutr. 108, 145.

Levander, O. A., Morris, V. C., Higgs, D. J. \& Ferretti, R. J. (1975). J. Nutr. 105, 1481.

Mutsuki, T., Yubisui, T., Tomoda, A., Yoneyama, Y., Yakeshita, M., Hirano,M., Kobayashi, K. \& Tani, Y. (1978). Br. J. Haemat. 39, 523.

Powers, H. J. \& Thurnham, D. I. (1976). Nutr. Metab. 21 (Suppl. 1), 155.

Powers, H. J. \& Thurnham, D. I. (1980a). Proc. Nutr. Soc. 39, 17A.

Powers, H. J. \& Thurnham, D. I. (1980b). Biochem. Soc. Trans. 8, 195.

Powers, H. J., Thurnham, D. I. \& Dugdale, A. E. (1981). J. Theor. Biol. 88, 685.

Scott, E. M. \& McGraw, J. G. (1962). J. biol. Chem. 237, 249.

Thurnham, D. I. \& Stephen, J. M. L. (1975). Xth Int. Cong. Nutr., Kyoto, 1975 Abstr. 6304 p. 303.

Turner, B. M., Fisher, R. A. \& Harris, M. (1974). Clin. Chim. Acta 50, 85.

Voss, M. D., Vorsanger, E. \& Spear, P. W. (1964). Clin. Chim. Acta 10, 21.

Wilkinson, J. H., Baron, D. N., Moss, D. W. \& Walker, P. G. (1972). J. clin. Path. $25,940$. 